

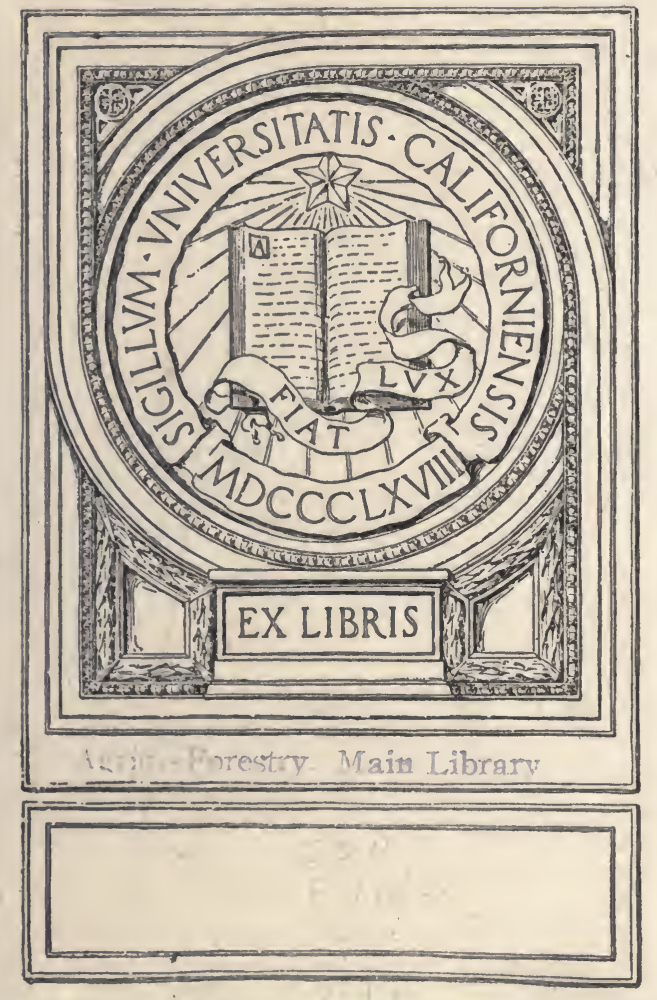





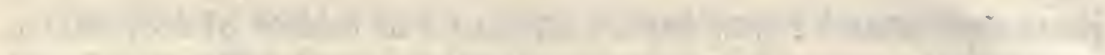

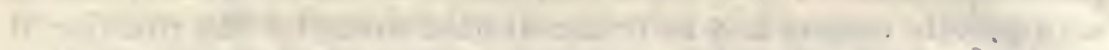

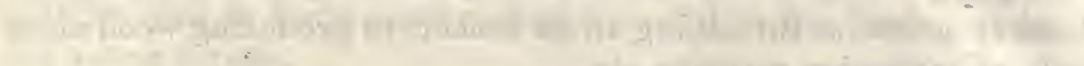

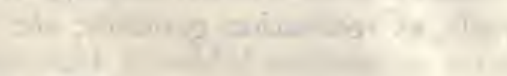

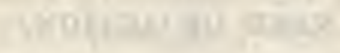

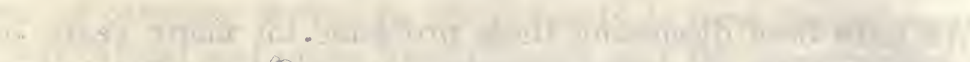

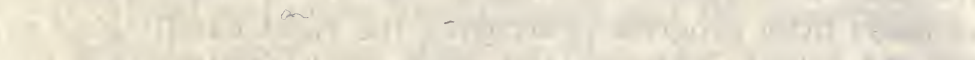

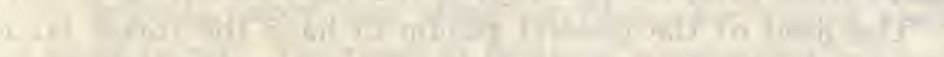

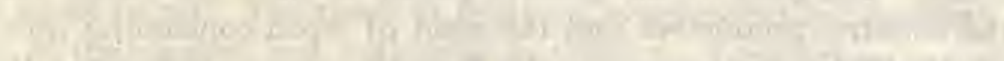

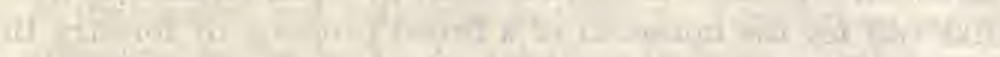

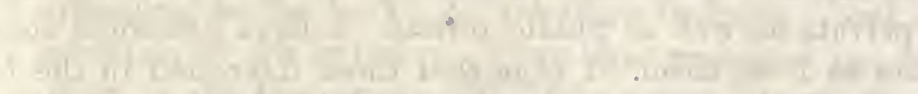

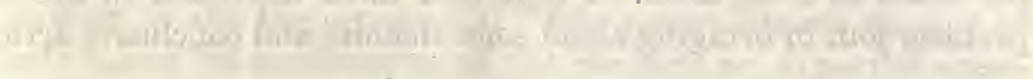
$+1$

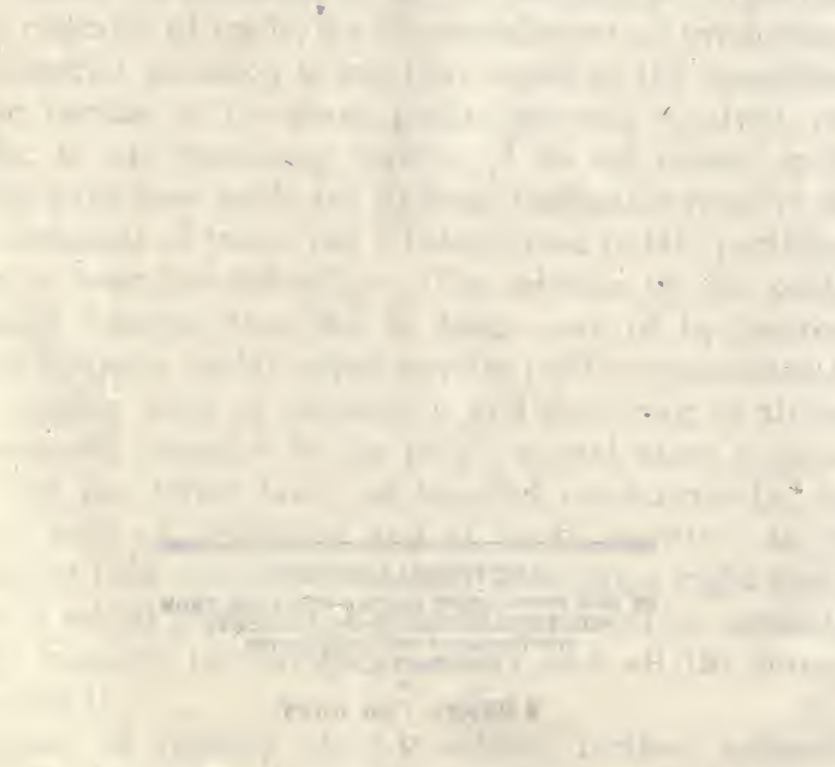




\title{
A NATIONAL LUMBER AND FOREST POLICY
}

\author{
By \\ HENRY S. GRAVES
}

Forester, Forest Servico

$\nabla$

Address before the American Lumber Congress, Chicago, April 16, 1919

\section{UNITED STATES DEPARTMENT OF AGRICULTURE CIRCULAR 131 \\ OFFICE OF THE SECRETARY}


HagNOI IAṼOTTAV /

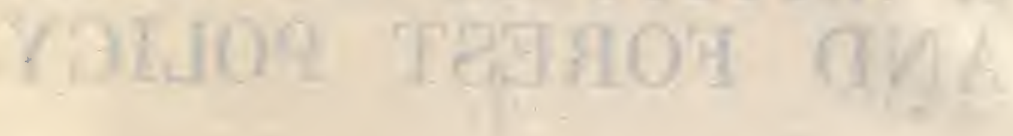

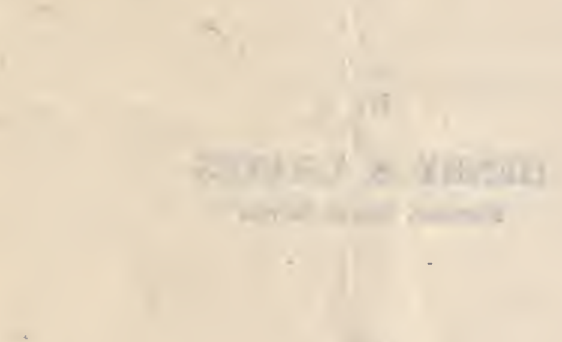

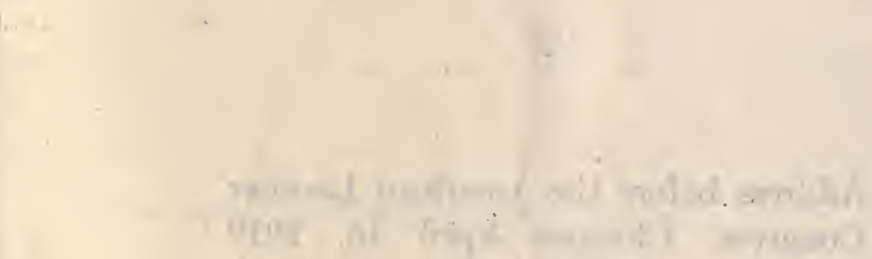

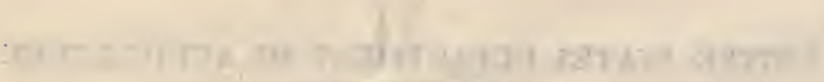

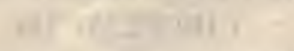

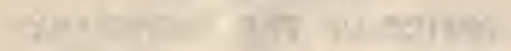

$1040+2$ 


\section{A NATIONAL LUMBER AND FOREST POLICY.}

The policies of the Government and the States during the next few years in matters relating to forests and lumber will be of farreaching importance. Conditions created by the war present certain problems of urgent interest to the lumber industry that will require definite action by the Federal Government. Among them are problems of railway transportation, exports, ship tonnage, taxation, labor relationships, and special questions relating to the orderly transition to peace-time conditions. There are other conditions and situations, however, which both from the standpoint of the lumber industry and of the general public welfare demand constructive action.

\section{VITAL INDUSTRIAL AND PUBLIC INTERESTS INVOLVED.}

The fundamental economic situation that has heretofore kept the lumber industry in a state of unstable equilibrium still exists. Labor problems, in considerable part due to the unsound industrial situation, loom up with no permanent adjustment in sight. The dissipation of our forests goes on with no let up, and still for the most part without any provision for the continuance of the forests after lumbering. Exhaustion of local forest supplies, the closing of industries dependent on them, the embarrassment for supplies of the pulp mills and other consumers using special classes of forest products, the generally mounting prices to consumers, are other factors which are calling sharp attention to the effect of forest destruction, and are causing increasing public uneasiness.

Lumbermen are giving thoughtful study to the needs of the industry; and they recognize that many things of a helpful and constructive character can be done within the industry itself in the way of cost accounting, adaptation of manufacture to the needs of the trade, scientific merchandizing, economies in manufacture, conservatism in finance, diffusion of information about prociuction, markets, price morements, existing stocks and shipments, and so on. I judge that progressive steps are rery generally under way in such matters, and that lumbermen are going as far as they can to improve the internal situation. There are other things that can be accomplished through cooperation with existing public agencies, as in economic, 
industrial, and technical research, and in demonstration of technical methods. I believe that a great many valuable things for the lumber industry can thus be brought about.

But neither the lumber industry nor the public can ignore the fact that the great fundamental problems, which not only involve the permanence and stability of the interests dependent on our forests but also gravely affect the national welfare, are not being solved. These problems fall into four general groups-those relating to the causes of overproduction, those that concern the supply, character, wellbeing, and stability of labor, the problem of the continuance of private forests and of stumpage supply, and certain questions relating to our public forests.

\section{THE LUMBER INDUSTRY STILL UNSTABLE.}

We must frankly recognize the fact that the elements that caused the unstable condition of the lumber industry prior to the war still remain, and constitute a danger for the future. To recall the situation at that time and the principal cause of trouble would be only to repeat the oft-told story of the speculative character of ownership of timberlands, the pressure to liquidate, the difficulties of financing stumpage, the excess mill capacity, the unorganized character of the industry, and various like matters; all contributing to cause premature cutting and overproduction, with its depression, losses, failures, interrupted operation, intermittent employment, and other ills. We may be able to point out certain elements of strength that may tend to steady the industry for a time, but we still have a great factor of uncertainty in the existence of large bodies of timber which their owners are seeking every opportunity to place on the market; and on many cases will be forced even at a loss to manufacture, because of financial pressure. Whenever markets improve there is the inevitable tendency to increase production to utilize surplus mill capacity, and there are always interests ready to inaugurate new mill enterprises when improved transportation or other factors seem to offer a favorable chance for an undertaking.

These are essentially the conditions that make for a periodic overflow of production and create unstable conditions. Some persons may be so favorably situated in the matter of high-grade products, low-cost production, or other factors, that they can meet even the extraordinary fluctuations of industrial conditions. But for the industry as a whole there exists an element of uncertainty because of the urgent pressure of stumpage for production. I do not see how there can be a permanent basis of conservatism, stability, and individual strength so long as this condition exists.

The public is concerned because of the injury and loss that accompanies demoralized industrial conditions, and because under such 
conditions there is increased waste in lumbering, protection from fire is less efficient, and the difficulties in the way of forest replacement are intensified. Failures that occur at such times often result in a transfer of lands, thereby increasing the tendency to centralization that may operate disadvantageously to the public in the long run.

\section{THE LABOR PROBLEM.}

Of far-reaching importance both to the industry and to the public is the problem of labor. It is the problem that is most insistently pressing, and perhaps in some aspects the most perplexing of any before the industry. Some features are peculiar to the lumber industry, and the ultimate solution will doubtless require a program especially adapted to the conditions of the forests and the sawmills. Temporary adjustments will doubtless be found, but a final solution will come, I believe, only with the placing of the lumber industry on a basis of stability and permanence.

\section{THE PROBLEM OF WANING TIMBER SUPPLIES.}

Any serious consideration of the conditions requisite to a sound lumber industry brings us face to face with the question of riv materials, the husbanding and careful use of existing supplies, and the renewal of our forests after lumbering. We have been lulled into a feeling of security in recent years because we have an estimated total quantity of standing timber in excess of twenty-five hundred billion feet. The very situation to which I have referred of industrial instability due to the pressure of large quantities of stumpage for production adds to the impression that we have so much timber in reserve that we do not need to concern ourselves about supplies of forest materials. Not only the public, but many economists, have been misled by statistics showing the aggregate of timber still stand- . ing in the country.

Forest depletion is injurious long before the last tree is cut and long before all but the last center of production is exluausterl. Oftentimes our minds are centered on total production and general markets, overlooking the relation of the forest and its inclustries to the life of the regions and the communities in which they are located. When local resources are so depleted that industries close, the question of vanishing supplies takes on a new significance. And that is exactly what is happening in hundreds of communities. The forest supplies are used up; the chief inclustry, a sawmill, a box factory, or a wood-working establishment closes. Subsidiary industries dependent on the primary undertaking have to close also. And what is more, the land formerly producing the timber, if nonagricultural, is left in an unproductire condition and a burden for many years on the community. 
Many important wood-using industries are already embarrassed for supplies. Especially acute is the situation faced by the manufacturers of news print paper in the Northeast, in the Lake States, and elsewhere. Enormous investments have been made in permanent mills, water power, and equipment. The local sources of supply of pulp wood are becoming rapidly exhausted. Because of this situation and because of the difficulties in obtaining raw materials from Canada, we have seen the new construction of mills taking place only in Canada, largely with American capital.

Other industries using special wood products are equally embarrassed. Some are able to secure materials from a distance; others have to close and move to new sources of supply.

Because there is still an abundance of timber in the far West, the East and central West can not complacently see the basis of their own industrial prosperity destroyed. In short, wo have in many: localities a very real problem of shortage of forest supplies and very. real consequences of forest depletion.

\section{FOREST RENEWAL NOT PROVIDED FOR.}

The problem of supplies does not merely concern the amount and and character of timber now standing, it concerns, as well, the production of new crops of timber by growth. I would have little concern about the amount of timber used if we were growing new stands in place of the old. We have enough nonagricultural land to produce for all time lumber in abundance for ourselves and for export. But this would require keeping our forests in a productive state after lumbering. We are not doing that. Our forests are steadily deteriorating under eutting and fire. No effort is made for replacement after cutting. Fire protection is confined to old timber. Young growth and cut-over lands are not being protected. Accidental stands following cutting and fire are generally poor in quality and species and of low prospective yield. We are still drawing for the most part on original sources of supply. Failing to replace these, we are steadily losing ground. We are actually using up our forests, just as we would use up a deposit of coal, when we might have been renewing them.

The question of forest renewal and growth is one that can no longer be ignored. It is not only of interest to the public but it is of vital concern to the owners of timberlands. It may be said that reserves of timber ought to be held by the public rather than by private owners. A good many assert that the growing of timber is wholly a public function; that as most timberland owners have bought their property to exploit their timber, not to grow trees, forestry and forest growth are not matters of private concern. But the fact remains that the bulk of the timber of the country is pri- 
vately owned, three-fourths of it. It is an important fact also that the bulk of the land that must grow the timber of the future is privately owned.

The transfer of the great bodies of timber from public to private hands was a grave mistake of public policy. It is not possible to conceive of a method better calculated to bring about a rapid dissipation of our forests than was actually used by the Gorernment in disposing of its timberlands, nor could a surer method have been devised to bring about a condition of industrial uncertainty. The lands were parceled out as fast as possible in small lots and under conditions that inevitably encouraged speculation. It was only a question of time that every owner should undertake to dispose of his land or timber to realize on his speculation. We now see that a different method of administering the public forests should have been adopted. But the action was taken and we can not undo it, nor can we ignore the problems that are resulting from it. The custody of the bulk of our forest resources was intrusted to private owners. The burden of carrying the timber and properly caring for it was transferred from the public to private hands. Whether they like it or not, the private owners have the problem of the right handling of a large part of our forests actually on their hands.

\section{AN IMPOSSIBLE SITUATION.}

On the other hand, the public has a rery essential interest in the question of keeping the lands in a producing condition so as to render a maximum of service, in supporting industries and local communities, and in serving to support through tax levies public enterprises of various kinds. Even though the public has surrendered its direct ownership of the timberlands, it can not afford to permit them to be handled in a way to be injurious to the welfare of the community. The various benefits required of forests, from their products, support of industry, etc., can be obtained only in part from the existing public forests. They are not extensive enough or widely enough distributed to meet more than a part of the public needs. We must continue to rely in considerable part on private lands, both for present supplies and for growing timber for the future.

We have, then, a perplexing dilemma. On the one hand the public is deeply concerned that the prirate forests be handled in a way to provide for forest renewal and growth. We have, on the other hand, the timber owners struggling under a responsibility that has never been fully sensed or accepted. The result is that while considerations of public interests demand that something be done, nothing substantial is actually being accomplished. It appears to me that the situation is an impossible one, that can not long continue. Both the 
industry and the public have a definite decision to make. As I see it, either private owners must assume the full responsibility of properly caring for their timberlands, including protection and forest renewal; or the public must take over the responsibility that it once had and surrendered; or the public must share with the owners both the responsibility and the burden of securing the objectives that are essential to safeguard the public welfare. My own view is that the last is the only fair and practical method from the standpoint of all concerned.

\section{PROBLEMS RELATING TO PUBLIC FORESTS.}

But there is a fourth group of problems. Not all of the forest lands passed into private hands. When the policy of deeding away the public timberlands was at last found to be an unsafe one for the Nation, it was changed and the bulk of the remaining public timberlands were withdrawn from private appropriation and segregated as National Forests. In this way about $155,000,000$ acres, nearly all in the western mountains, were reserved. For these public timberlands the public is doing what should also be done for the timberlands that passed to private owners. The public forests are being protected from fire, the timber is used as it is called for by economic conditions, and the curting is conducted by such methods as leave the land in favorable condition for the next crop of timber.

There are definite policies of handling our National Forests and their resources. There is, however, no public or national policy that takes into consideration all the forests of the country and correlates their problems and development. This is true also of the regions in which the public forests are located. The manner in which the public timber is handled may vitally affect the lumber industry. The problems of the lumber industry may affect the interests of the Government in the administration of its own forests. There remains yet to determine what shall become of the cut-over nonagricultural lands, to what extent these shall be taken over by the public, especially those on critical watersheds and on steep slopes. There are various other questions relating to public forests, their extension and use that require to be considered in connection with any program that looks to the whole forest situation of the country.

\section{A BROAD PROGRAM NEEDED.}

The problems which I have set forth touch many interests, both public and private. Their solution involves Federal and State legislation; and also involves cooperation between public agencies and the lumber industry. The different problems are closely interrelated one with another. Moreover, action in one section of the country concerns the interests of other regions. These circumstances make it 
clear that for a final solution there must be a far-reaching program that will enable the Federal Government, the States, communities, and the industrial forces to unite in a common effort.

Such a program should be comprehensive enough actually to accomplish the objectives sought by the public and essential to the permanent well-being of the industry. Many efforts have been made io find a solution for some industrial features or some public features of the forest and lumber problems, and have failed because they left out of account some outstanding question that must be solved at the same time. Let me illustrate:

\section{REMEDIES HITHERTO PROPOSED INADEQUATE.}

It has been suggested that the problem of periodic overproduction could be met by modifying the Sherman Act in a way to permit agreements to curtail production when justified by industrial conditions. You will recall that this was proposed when the Clayton Act was under discussion; and in 1916 the proposal was put forward very specifically in a referendum from the United States Chamber of Commerce. It is out of place here to discuss in detail this proposal. There are, however, two defects that are pertinent to the present discussion.

This suggestion was offered to the country as a conservation measure. You will recall the language of the referendum, that "there should be remedial legislation to permit cooperative agreements under Federal supervision in those industries which involve primary natural resources, on condition that the agreements in fact tend to conserve the resources, to lessen accidents, and to promote the public interest." The report of the Chamber indicates that the question of handling the forests - that is, forest protection and forest production-is not a part of the plan. This means that the only conservation so far as lumber is concerned would be the saving of a measure of waste made possible through the more stable and advantageous trade conditions. The vital object of the public to secure a continuance of the forests is wholly left out of account.

A second serious defect is that it would not, in my opinion, be really effective in bringing about a condition of permanent stability. The forces that tend to throw an excess of lumber on the market are too strong. Lumbermen often say themselves that a lumber combination could not really exist because sooner or later some one would be unable to stand the pressure, and the usual break of market would occur. This is doubtless true, and applies also to such an arrangement as that contemplated in the proposed change of the Sherman Act. 
In short, the proposal does not reach the real source of the difficulty and would not be of permanent benefit to the industry, aside from its failure to safeguard various general public interests.

A second suggestion that has been made is that the public cooperate in the conservative financing of timber holdings through longterm loans at low rates of interest. Some have suggested a system of forest loans backed by the public credit, similar to the loans made to farmers under the farm loan act. The theory is that the financial strengthening of the stumpage holdings would act automatically to cause curtailment when the market is overloaded and prices are likely to fall. This proposal points directly to the greatest weakness of the industrial situation, but, like the previous plan it is a halfway measure. It does not malie any provision for the permanence of the forest.

Still, again, tax reform has been urged for a decade or more. On the ground that the present system tends to force premature cutting, it is proposed that there should be an annual land tax and a tax on the product when it is cut. The present tax system without question opcrates to discourage the holding of land for growing timber. But there are other forces much stronger that are causing premature cutting and that are preventing the owners from caring for the cut-over lands. Taken alone tax reforms will not achieve either result.

I can further illustrate the failure of halfway measures by reference to various proposals which have also been made regarding the protection and reproduction of the forest. Most of these concern fire protection, and largely leave out of account the question of forest replacement. Specific proposals, however, have been made to place legal restrictions on methods of operation in the wocds. In a numher of States such proposals have been widely discussed, bills have been offered in the legislatures, and there is behind them a very considerable body of public sentiment.

These have made little headway, because for the most part they hare not provided for meeting certain economic difficulties. Here again the industrial problems must be considered along with the proposals to secure forest renewal and growth.

In approaching the question of a national lumber and forest program, involving perhaps some radical departures from the present principles of relations between the public and industry, we shall find, I beliere, that the most important and fundamental questions relate to the speculative character of forest ownership. Such ownership means cutting as fast as possible and without reference to how the land is left after lumbering. What is needed is some strengthening influence that would make possible the husbanding of the resource and its conservative use, as the public would use it if it had retained 
control over it, and at the same time provicle for the continued productiveness of the land.

If the public had retained title to forest lands it would have been able to dispose of timber as it is needed; it could have secured orderly development and built up permanent enterprises, secure in a perpetual supply of raw material; it would have been able readily to organize protection and to secure forest replacement. The public can not recover the position it surrendered, yet it may be possible to bring about in a measure the objectives we have been discussing.

\section{WHAT AN ADEQUATE PROGRAM SHOULD INCLUDE.}

No single measure or action will meet all features of a lumber and forest problem. Each region will have a group of problems. Each region will require special consideration because of the peculiar local conditions. The required measures for the different regions, correlated for the whole Nation, is the thing to be sought in the making of a national program. I can at this juncture only indicate what I believe should be the general objectives and the spirit of approach, and point a way to secure some definite action.

I am ready to adrocate a policy more far-reaching in all respects than has generally been offered. I would afford whatever public assistance is needed to make possible the conservative handling of our forests, and I would then make fire protection, conservative production of lumber, and right methods of removal a matter of requirement, with such public direction and control as is necessary to realize the aims desired by the public.

Just what this action should be may vary in different regions. It may be a combination of several methods of public cooperation. It is possible that the principle of conservative financing with public cooperation may be applicable under some conditions. I would not hesitate to concur in such a principle provided it is a part of a plan that includes the accomplishment of the various public objectives of a broad forestry and lumber program. Circumstances will require a correlation of production, with the economic needs of the country as one feature of a large program that guarantees the continuance of the forest. It should be under a system that makes the public a definite party to the undertaking and in a position to safeguard by direct action the various public interests.

Still, again, in some localities the tariff, or local taxation, may play a large part in the industrial and forest situation. In such a case I would meet these problems in the light of the needs of the permanent industrial life of the region, not of a group of industrial interests alone. 
The adjustment of international relations, the reform of taxes, or other public measures taken to aid industry should be considered in connection with the question of constructive handling of the timberlands. Already a number of lumbermen of the Northeast have stated to me that they would support a program that would make good forest practice a requirement, provided the public cooperated in removing the real obstacles now existing, and also provided that the requirements which might be imposed were made applicable throughout the region without discrimination.

It is possible that where public and private lands are intermingled and economically interrelated, as in the West, a still more farreaching principle may be desirable; one that would coordinate all forest lands within economic groups so that they can be dereloped in a way best to meet the needs of the country and the communities. It has already been found necessary to coordinate and handle jointly all forest lands, regardless of ownership, with respect to protection from forest fires. A joining of hands of the public with industry in carrying out and administering the great private resources of timber so as to prevent the present waste and uneconomic orerproduction and at the same time to insure forest renewal is a distinct possibility. Under such a plan there would be public control of such features as concern the public welfare, and the industry would handle its part under conditions that would permit full play of individual initiative and enterprise. At the present time the mixed character of ownership tends to prevent an orderly derelopment that builds up and sustains communities.

In all regions there is needed a broad policy of forest development, a policy which makes for permanent mills and all that means to the einployment question, which places timber on the market only as it is needed, which protects the present resource-a difficult matter now eren under the most earnest efforts to cooperate-and. which classifies the lands, encouragos agriculture, puts to its best use every acre, and secures tree growth on nonagricultural lands.

Is not such an outlook worth while for the public? And is it not likely that the country would support such a plan if it could assure itself that the public benefits would be secured? Certainly it could afford to give its financial credit and authority, provided its interests are safeguarded by adequate control placed in public hands.

These are suggestions made to indicate the character of the cooperation the public might lend and the sort of requirements it should exact. I have discussed a few of the principles, aims, and problems of a national policy. I have emphasized particular points because of their importance and because they are the ones most likely to cause difficulty. A national program should include many other features, 
stich as Federal taxation, export problems, legislation and cooperation in fire protection, economic and technical researeh, etc.

One of the important problems is that of extending the public forests. 'There are many areas in our mountains which are so important from the standpoint of protection of the slopes and of water resources that they should be owned by the public. Private owners can not handle them properly, even under the most favorable conditions. There are also large areas of cut-over lands that would render their best service in public hands. Most of this land has been badly injured and is now carrying but little forest growth of potential value. The public should acquire large areas of such land and gradually restore it to productive use.

In view of the situation regarding cut-over nonagricultural lands and the steps that must be taken to restore them, I am in favor of a greatly enlarged program of acquisition on the part of the Federa] Government and the States. The Federal Government has been accuiring cut-over and culled lands in the Southern Appalachians and White Mountains at the rate of about $\$ 2,000,000$ per year since 1911, and the plan has worked out most successfully. Some of the States, too, are engaged upon programs of acquisition. New York State, with already a holding of nearly 2,000,000 acres, has roted bonds for $\$ 7,500,000$ to be expended for this class of lands. Cities also should undertake the acquisition of forest lands, especially those tributary to their city watersheds. This policy should be pursued until large areas of cut-over land, second-growth forest, and protective forest.have been restored to public ownership. These publicly owned forests should be well distributed through all the forest regions. Is these areas are acquired, they should be organized as Municipal, State, or National Forests.

\section{EARLY ACTION URGENT.}

We may discuss these questions in meetings and conferences and accomplish little. We have the problems to solve, and we can not continue to ignore them. I regard the industrial problems as very urgent. Some action is inevitable in regard to the question of better forest protection, of forest renewal, and growth after logging. Public demand for action is increasingly insistent. Now is the time, therefore, to bring about action in accordance with broad constructive plans, rather than by piecemeal legislation by different States, uncorrelated with each other, and with action of the Federal Government.

I have taken it upon myself to ask for cooperation in laying the groundwork for a national policy. I have already initiated a series of conferences with forest agencies of the States and with representa- 
tives of interested institutions and organizations. I hope that the lumbermen will concur in the need of such a movement as I am proposing and will join in the undertaking to work out a constructive program. Specifically, I hope that there may be some official delegation of authority to representatives of the different branches of the industry to work with the Forest Service and other agencies in preparing a basis for the solution of our forest and lumber problems.

April 16, 1919. 

GENERAL LIBRARY

UNIVERSITY OF CALIFORNIA-BERKELEY

RETURN TO DESK FROM WHICH BORROWED

This book is due on the last date stamped below, or on the date to which renewed.

Renewed books are subject to immediate recall.

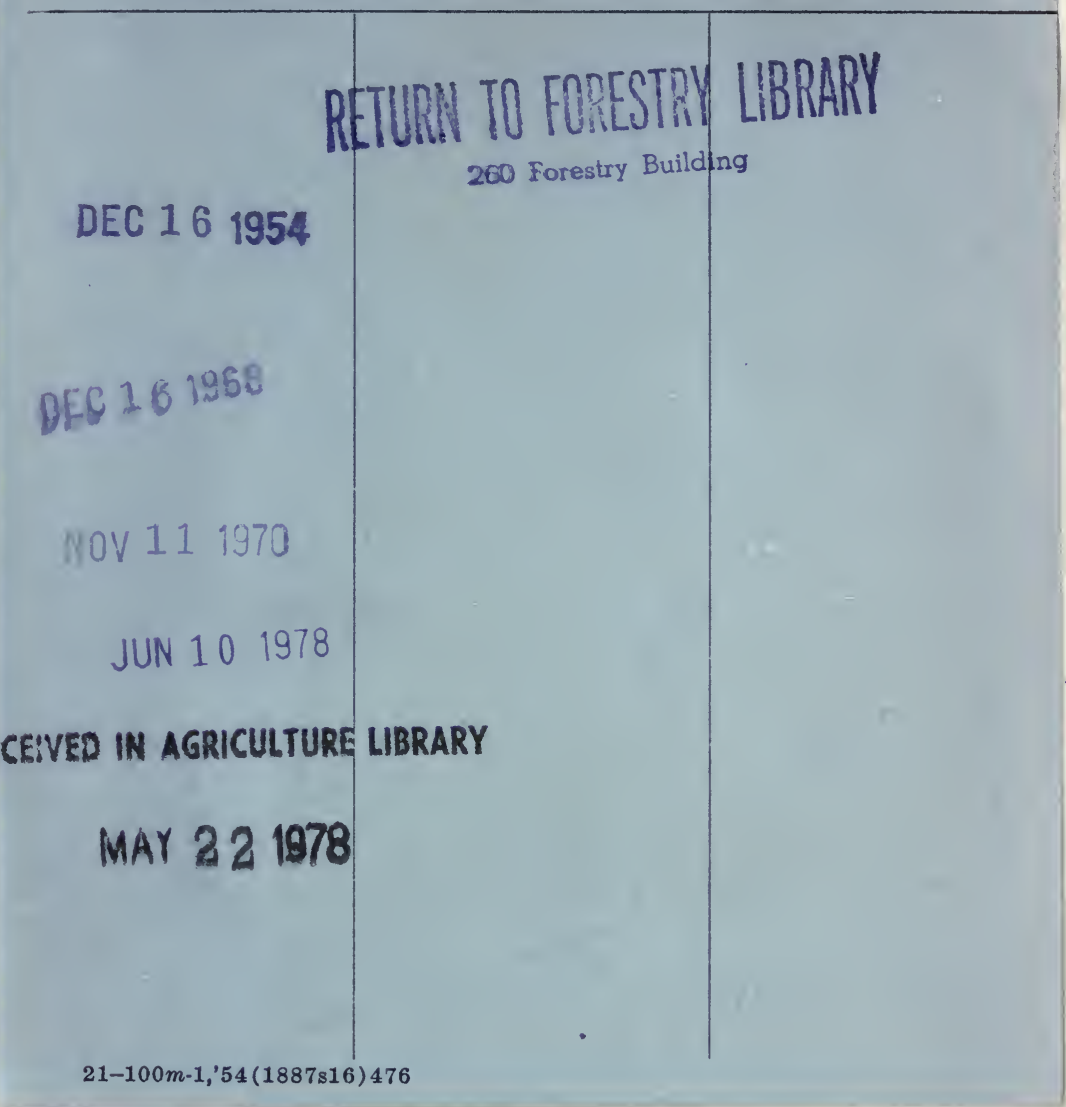




$$
\begin{gathered}
\text { SD } 121 \\
\text { P3 } \\
V .14 \\
+ \pm
\end{gathered}
$$

$$
\text { Yis }
$$

THE UNIVERSITY OF CALIFORNIA LIBRAA'RY S S 


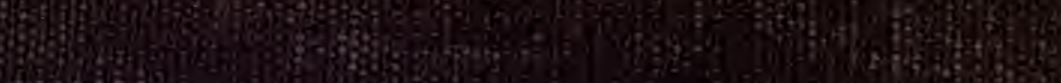

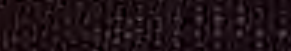

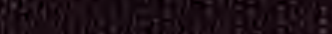

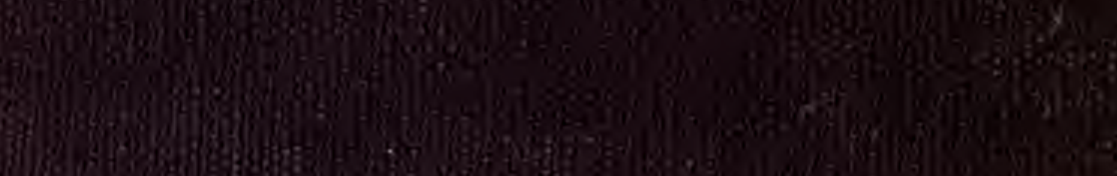

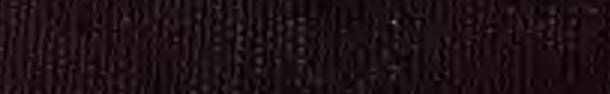

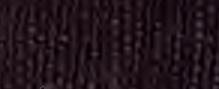

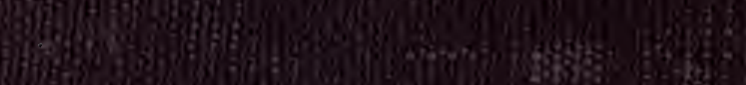

6. III. f

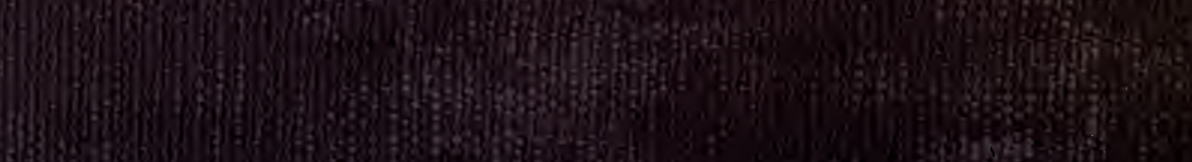

18.

song

56) 3.

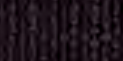

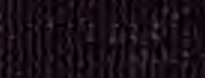

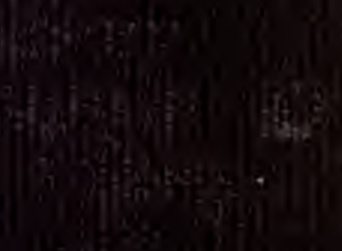

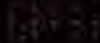

Hos.

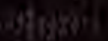

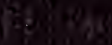

